\title{
NEWER ANTIBIOTICS IN THE TREATMENT OF VENEREAL DISEASE*
}

\author{
BY \\ RAYMOND C. V. ROBINSON
}

\begin{abstract}
From the Venereal Disease Division of the Medical Clinic of the Johns Hopkins University and Hospital, Baltimore, Maryland
\end{abstract}

When the effectiveness of penicillin in the treatment of syphilis was first demonstrated, a group of the larger syphilis clinics throughout the U.S.A. coordinated their efforts, and the results were analysed by a central statistical unit. As a consequence, evaluation of the drug, at least in early syphilis, progressed so rapidly that the older methods of therapy became obsolete 4 or 5 years ago.

Aureomycin became available in 1948 and was followed shortly by chloramphenicol and terramycin. Though it was quickly discovered that all three drugs exerted some effect on each of the venereal diseases, there was no attempt to duplicate the cooperative study carried out with penicillin. This has led to the publication of a great many articles by independent investigators; in some instances the results of various investigators in the same field are contradictory, perhaps because of differences in dosage schedules, diagnostic criteria, and post-treatment observation periods, and these contradictions have caused confusion.

Two years ago I reviewed the effects of aureomycin and chloramphenicol in the five venereal diseases (Robinson, 1950a), and since then new data have appeared concerning these drugs. Terramycin has become available, cortisone has been found to exert a beneficial effect on the course of syphilitic interstitial keratitis, and, although the great bulk of literature still originates in the United States, the newer antibiotics are being increasingly investigated in Europe, particularly in Great Britain, where studies have been pioneered by Willcox, Findlay, and Nicol. It seems desirable, therefore, to review the literature of the past 2 years, to describe some personal observations, and to attempt to correlate data from the various reports.

Although I propose to discuss primarily the effects of aureomycin, chloramphenicol, and terra-

\footnotetext{
* Read at the Tenth Annual Meeting of the American Academy of Dermatology and Syphilology in Chicago on December 12, 1951 . Received for publication January $29,1952$.
}

mycin on the five venereal diseases, I shall also refer to the action of cortisone in experimental and clinical syphilis, and to the recent advances in the treatment of yaws.

\section{Cortisone AND AdRenocorticotrophic HORMONE (ACTH)}

EXPERIMENTAL SyPHiLIs.-The discovery during the past 2 years that cortisone and ACTH alter the natural course of syphilitic infection is of great significance.

Turner and Hollander (1950) found that under the influence of cortisone therapy, syphilomata induced in rabbits by intradermal or intratesticular inoculation of Treponema pallidum showed striking alterations from the usual syphilomata, the lesions becoming soft and spongy, with an accumulation of mucoid material tentatively identified as hyaluronic acid. T. pallida became abundant and the usual production of reagin in the serum was inhibited. When penicillin therapy was instituted in these rabbits, large numbers of dead spirochaetes were seen within 24 hours, but none was found in those animals not treated with cortisone. The University of Pennsylvania group (DeLamater and others, 1951) also reported a marked increase in the number of spirochaetes in the lesions of experimental rabbit syphilis when cortisone was administered in the incubation period. They observed that when cortisone was given in chicken spirochaetosis, a fulminating infection resulted, with the production of few antibodies as contrasted with the usual high degree of immunity. Sheldon, Heyman, and Evans (1951) did serial biopsies on rabbit syphilomata during therapy with ACTH and concluded that the hormone failed to inhibit the JarischHerxheimer reaction.

Early Clinical Syphilis.-Working with T. R. Wells, I have administered cortisone orally to three 
patients with darkfield positive lesions. In each instance the lesions became dry and darkfield negative within 48 hours. When cortisone therapy was stopped, a rebound phenomenon took place, the lesions again becoming moist and larger in size. Subsequent penicillin therapy caused the lesions to heal, and the post-treatment fall in the S.T.S. titre followed the usual pattern of penicillin-treated early syphilis. The small number of patients involved does not allow of any conclusions being drawn. A much larger series is necessary to explain why human infection apparently reacts in a different manner from rabbit syphilis.

INTERSTITIAL KERATITIS. - The effects of cortisone and ACTH on syphilitic interstitial keratitis have been studied by several investigators (Wilson, 1951 ; Scheie and others, 1951; Leopold and others, 1951 ; Fitzgerald and others, 1951 ; Geddes and McCall, 1950 ; Simpson and others, 1951 ; Olson and others, 1951). Three series of patients which seem to summarize the various views on the subject are discussed below in some detail :

(1) In a group of patients treated with topical cortisone by Crane and McPherson (1952), eight of seventeen eyes developed at least one exacerbation, and two were treated a third time. These recurrences occurred within 15 days to 5 months of cessation of therapy. Recurrences were noted in six of eleven eyes in which corneal vascularization was present before initial therapy, and in two of six eyes in which vascularization was not evident before treatment. Subjective relief was experienced in every case within 4 days and progress of the keratitis in sixteen of the seventeen eyes was arrested within 10 days. The drug was equally effective in controlling primary and recurrent attacks.

(2) Woods (1952) discussed the results obtained in nine patients treated for syphilitic interstitial keratitis at the Wilmer Institute of the Johns Hopkins Hospital. One case was treated with ACTH alone, one with a combination of ACTH and topical cortisone, and seven with topical cortisone either as drops or as ointment. The first patient had been previously treated extensively with parenteral and sub-conjunctival penicillin and metal chemotherapy without benefit. A prolonged course of ACTH failed to cause improvement and the patient was discharged practically blind. A second patient failed to respond to ACTH but improved on topical cortisone. The next seven patients received only topical cortisone as drops or ointment. There were relapses in all cases where treatment was abruptly stopped after initial improvement. Woods concludes that cortisone controls the inflammatory and exudative phases of the disease but does not act on the cause. If the disease is in the early stages of inflammation, topical cortisone gives immediate symptomatic relief, and if the treatment be continued through the natural course of a self-limited attack it may even result in cure of the local lesion. The more advanced the disease, the less the effect of cortisone. In the stage of necrosis, there is no effect.

(3) Klauder (1951) is not enthusiastic about the local use of cortisone because of the incidence of recurrence. He has seen recurrences weeks and even months after cortisone was discontinued.

In an editorial discussion of the subject, Woods (1951) states that the conflicting results may be due to the basic pathology of interstitial keratitis and the time at which treatment was started.

Although there is some disagreement regarding the general picture, there appears to be little doubt that cortisone, applied locally in the form of drops or ointment, exerts a beneficial effect when therapy is instituted early in syphilitic interstitial keratitis, and if it be continued long enough there may even result an apparent clinical cure. Since exacerbations seem to respond as readily as the initial inflammation, and since no currently accepted method of treatment has been universally successful, the use of this drug is recommended, preferably in conjunction with specific therapy of the syphilitic infection with penicillin.

Summary.-Because cortisone has been shown to affect the course of lesions of early syphilis and may, therefore, alter the progress of the disease in its later phases, caution should be exercised in its use in any patient with syphilis unless concomitant treponemicidal treatment is also given.

\section{Aureomycin, Chloramphenicol, AND Terramycin Syphilis}

EARLY SyPHILIS.-Observations of the effects of aureomycin, chloramphenicol, and terramycin on the lesions of early syphilis continue to appear in the literature. There seems to be little doubt that all three drugs are effective and that there is little or no difference in the degree of effectiveness. Surface treponemata usually disappear in 24 to $48 \mathrm{hrs}$, and lesions of early syphilis heal within 5 to 7 days. There is, however, no evidence on which the final effect of any of these drugs in the disease may be estimated.

Schoch and Alexander (1950) state that terramycin is definitely effective in primary syphilis, but make reservations as to the final result. Hendricks and others (1950) gave doses of $60 \mathrm{mg}$./ $\mathrm{kg}$. bodyweight of terramycin hydrochloride, and noted prompt clinical healing of lesions of early syphilis. Keefer (1950), Robinson and Robinson (1951), and Olansky and Landman (1950), all noted that the drug was spirochaeticidal, treponemata usually disappearing within 24 to $48 \mathrm{hrs}$. 
Aureomycin is felt by Olansky and others (1950) to be therapeutically active in early syphilis. Robinson and Robinson (1950) noted healing of lesions in 7 to 14 days. Chen, Dienst, and Greenblatt (1950a) treated two patients with primary syphilis and noted complete healing of lesions. Kierland and others (1950) and Willcox (1949) noted marked action on human syphilis.

Robinson and Robinson (1949) treated several patients with early syphilis with chloramphenicol, and state that in 70 per cent. of their patients serological reversal was obtained. Willcox (1950a) states only that lesions healed within 6 days.

Gruhzit and Fisken (1950), using chloramphenicol in experimental syphilis of rabbits, found that the blood serum concentration in rabbits is relatively low in comparison with that in human subjects, and they concluded that this fact may account for the divergence of therapeutic effectiveness in rabbits and humans, since a larger amount of chloramphenicol per $\mathrm{kg}$. bodyweight is necessary to bring about healing of rabbit syphilomata.

SyPhILIS AND PregnaNCY.-Robinson and Robinson (1949) state that in their series two pregnant women with early syphilis treated with chloramphenicol were delivered of non-syphilitic infants. Olansky and Landman (1950) also claim that chloramphenicol and aureomycin are effective in preventing congenital syphilis, but qualify this by stating that their limited experience makes it difficult to say how effective. Six syphilitic pregnant women were treated. None of the infants showed clinical evidence of syphilis at birth but in one child, observed at the age of 2 months, secondary syphilitic lesions were present.

LATENT SyPhiLIS.-Romansky and others (1951) treated eleven patients suffering from early latent syphilis with chloramphenicol. They stated that the serological progress of all except one had been favourable, but that none attained sero-negativity in the follow-up period.

BENIGN LATE SyPHILIS.-Olansky and others (1950) state that chloromycetin and aureomycin produce quick healing in late skin syphilis. Kierland, Herrell, and O'Leary (1950) make the same observation using aureomycin. Romansky and others (1951) treated three patients with chloramphenicol. All lesions healed during the period of treatment, but there was one recurrence 2 months after treatment. They feel that the healing mechanism appears to differ from that seen in penicillin-treated cases.

NeUROSYPHILIS.-Romansky and others (1951) treated five patients with syphilis of the central nervous system with chloramphenicol. At the completion of 15 days' treatment, the cerebrospinal fluid protein, complement-fixation reaction, and colloidal gold abnormalities showed no improvement, but the cell count had returned to normal. There was no improvement in optic atrophy after 6 months, and no improvement in a patient with symptoms of tabes dorsalis at the end of 8 months.

Kierland and O'Leary (1950) treated twelve patients with oral aureomycin and noted that the drug produced satisfactory clinical results and decreased the activity of the disease as measured by the cerebrospinal fluid changes. They concluded that aureomycin caused the same early beneficial results as penicillin. The cerebrospinal fluid of patients treated with aureomycin showed essentially the same response as that of patients treated with penicillin, the response appearing to be of the same degree and occurring with the same rapidity. Eleven out of twelve patients had Group III cerebrospinal fluid before treatment. The authors recommend that aureomycin by mouth is indicated for those patients with neurosyphilis who are resistant or hypersensitive to penicillin.

At the Johns Hopkins Hospital, with C. F. Mohr, I am studying the effects of aureomycin and chloramphenicol in asymptomatic neurosyphilis in patients with Group III cerebrospinal fluids (Mohr and Robinson, 1952). The results of our study so far are summarized in the Figure, which shows a rapid drop of the cell count to normal, while the response of the colloidal curve is slower. There have been essentially no changes in the total protein or in the complement-fixation reactions during the period of observation. Although the initial response in these few patients has been generally good insofar as reduction of activity in the cerebrospinal fluid is concerned, we do not recommend the routine use of these drugs in neurosyphilis until considerably more is known about their action. The treatment of choice is procaine penicillin 600,000 units daily or every other day to an approximate total of 10 million units.

Miscellaneous Conditions.-Poulin (1950) stated that four patients with ocular syphilis responded to aureomycin after other forms of antisyphilitic therapy had proved of no avail. Cantor (1950) stated that he was studying chloramphenicol and aureomycin in peri-anal lesions of syphilis but that evaluation was as yet incomplete and no definite views could be offered.

Summary.-In spite of the wealth of published material there is as yet no definite evidence that 


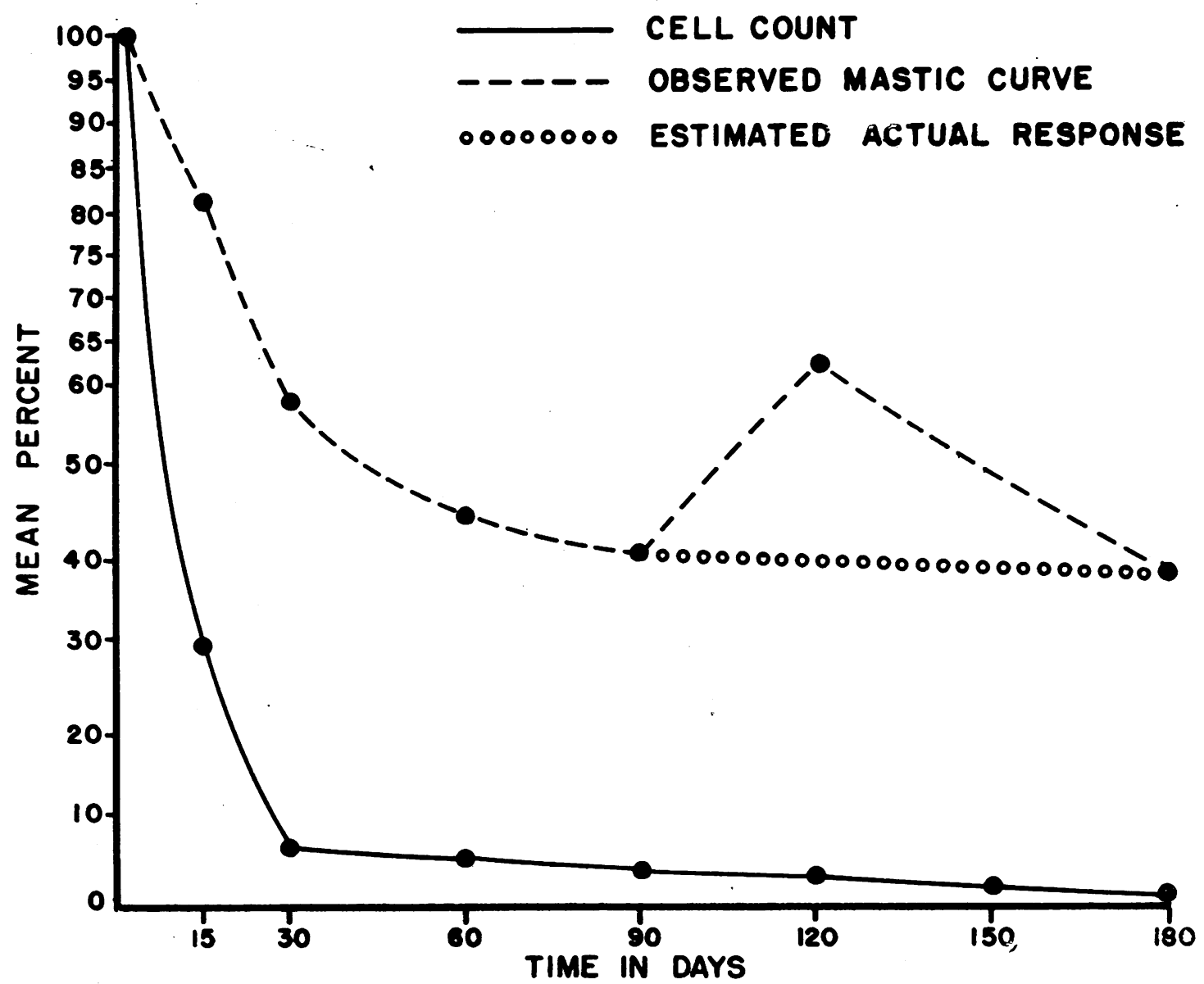

FIGURE.-Eleven patients with late asymptomatic neurosyphilis and Group III cerebrospinal fluids, treated with total doses of $60 \mathrm{~g}$. aureomycin or chloramphenicol over a 15-day period.

(Other than frequent gastro-intestinal upsets with aureomycin, there were no major differences in response to the two drugs).

any of the newer antibiotics is more effective than or even as effective as penicillin in the treatment of any stage of syphilis. However, the newer drugs have a place in the treatment of syphilis, in that they are valuable where there is a hypersensitiveness to penicillin. Therefore, in the absence of substantial evidence to the contrary, the treatment of choice is penicillin, preferably in the form of procaine penicillin suspended in water or oil.

Gonorrhoea.-There is apparently universal agreement on the effectiveness of aureomycin, chloramphenicol, and terramycin in the treatment of acute gonorrhoea in both male and female. Reports, most of which deal with acute gonorrhoeal urethritis in the male, continue to accumulate in the literature.

Hendricks and others (1950) treated 82 patients with oral terramycin hydrochloride in varying schedules. They found 100 per cent. cures with an initial dose of $1 \mathrm{~g}$., followed by a further $1 \mathrm{~g}$. after 2 hours. The percentage of cures dropped rapidly with decreasing doses. When 1.5 or $1.0 \mathrm{~g}$. terramycin hydrochloride was given as a single dose only one-third of the patients were cured. They concluded that terramycin effected a satisfactory cure rate in the treatment of gonorrhoea although the amount required for cure was somewhat higher than that necessary with chloramphenicol.

Beinfield and others (1951) compared the effects of oral terramycin and oral aureomycin and found that the two drugs were almost identical in their cure rates when given in similar quantities. All of their patients were treated with divided dose schedules. Their cure rates were uniformly high, even with $0.5 \mathrm{~g}$. repeated after 6 hours. They state that the cure rate obtained in this series is 
TABLE I

MALE PATIENTS WiTH GONORRHOEAL URETHRITIS TREATED WITH A SINGLE INTRAMUSCULAR INJECTION OF 1 G. CHLORAMPHENICOL SUSPENDED IN STERILE DISTILLED WATER

\begin{tabular}{c|c|c|c|c}
\hline $\begin{array}{c}\text { Patients Treated } \\
\text { and Observed }\end{array}$ & Failures & $\begin{array}{c}\text { Cure Rate } \\
\text { (per cent.)* }\end{array}$ & $\begin{array}{c}\text { Probable } \\
\text { Reinfections }\end{array}$ & $\begin{array}{c}\text { Optimum Cure } \\
\text { Rate (per cent.) } \dagger\end{array}$ \\
\hline 36 & 5 & 86 & 2 & 92 \\
\hline
\end{tabular}

* Considering all patients failures who were proven to have gonorrhoea at the post-treatment observation. $\dagger$ Not counting as failures those patients re-exposed.

"certainly as high as that obtained with intramuscular injections of penicillin ", and that these drugs may become the agents of choice in the treatment of gonorrhoea. Caldwell and others (1950) treated seven patients with gonorrhoea with terramycin for 4 to 5 days with resultant cures. Keefer (1950) remarks that terramycin is effective in the treatment of gonorrhoea. Sayer and others (1951) state that one patient with gonorrhoea improved after $1 \mathrm{~g}$. terramycin and was cured after a second similar dose. Schoch and Alexander (1950) found terramycin "very effective" in 26 cases of gonorrhoea.

In a group of patients whom I treated with oral terramycin (Robinson, 1950b), fourteen out of eighteen with gonorrhoeal urethritis were cured by a single oral dose of $2 \mathrm{~g}$., but only three out of six patients were cured after $1 \mathrm{~g}$. There was a high incidence of nausea as a reaction to the drug in this series; but a more recent study (Robinson and Oates, 1952) indicates that the use of a terramycin base may eliminate this untoward side reaction without impairing effectiveness. Gocke, Wilcox, and Finland (1950) also observed a high incidence of gastro-intestinal reactions following terramycin hydrochloride.

A preliminary report (Robinson, 1950b) indicated that a single oral dose of $1 \mathrm{~g}$. aureomycin was capable of curing 80 per cent. of cases of gonorrhoea in the male. Further observation (Robinson and Galen, 1951) on various dosage schedules indicates that there is no real difference in cure rates when $1.0,1.5$, or $2.0 \mathrm{~g}$. aureomycin are given as a single dose, the average being 79 per cent. This cure rate is not as great as the 95 per cent. cures obtained with 75,000 units procaine penicillin in oil.

Wright, Metzger, and others (1951) treated 63 patients with total amounts of $1 \mathrm{~g}$. aureomycin given in two doses of $0.5 \mathrm{~g}$. each. There were three failures in the group, giving a cure rate of 95.2 per cent. Toxic reactions were minimal, and these workers feel that aureomycin was as effective as penicillin in the treatment of acute gonorrhoea. Willcox and Findlay (1949) treated two cases of gonorrhoeal urethritis with oral aureomycin, one with $2 \mathrm{~g}$. and one with $1 \mathrm{~g}$., over a 24 to $60-\mathrm{hr}$. period. In both cases the disease responded favourably. Olansky and others (1950) treated two patients with acute gonorrhoeal urethritis and found that the discharge stopped within $24 \mathrm{hrs}$. Chen, Dienst, and Greenblatt (1950), in a series of 100 cases treated with two dosage schedules, found identical results in the two groups. Fifty patients were given $1 \mathrm{~g}$. aureomycin orally three times daily for 3 days, and fifty were given $1 \mathrm{~g}$. three times in one day. The cure-rate was 98 per cent. in each group. They conclude that $3 \mathrm{~g}$. seems sufficient to treat the average case of gonorrhoea. Toxic reactions were few and not serious.

Willcox (1950a) treated two cases of gonorrhoea with chloramphenicol, one complicated by a Cowper's gland abscess and prostatitis. In both instances the disease was cured. Olansky and Landman (1950) feel that $1 \mathrm{~g}$. aureomycin or chloramphenicol in a single dose is effective in the treatment of most cases of gonorrhoea. Greaves and others (1950) cured 96 per cent. of fifty patients with a single dose of $0.75 \mathrm{~g}$. chloramphenicol. They felt this to be a minimum effective dose.

A preliminary study of the effects of an intramuscularly administered suspension of chloramphenicol in gonorrhoea has recently been completed (Robinson and Wells, 1952a, b). One gram of the drug was suspended in $4 \mathrm{ml}$. saline and given intramuscularly to each of 51 males with gonorrhoeal urethritis. No untoward local or systemic reactions were observed. The cure rate approximates to that obtained with a single injection of 75,000 or 100,000 units of procaine penicillin in oil (Table I).

Gonococcal proctitis is being treated by Cantor (1950) but no conclusions have so far been reached.

Leopold (1951) felt that one patient with gonococcal conjunctivitis improved when chloromycetin was given systemically.

Gocke, Wilcox, and Finland (1950) have constructed an antibiotic spectrum for the gonococcus and have found that penicillin was by far the most active of the agents tested, aureomycin, chloram- 
TABLE II

GRANULOMA INGUINALE TREATED WITH AUREOMYCIN OR CHLORAMPHENICOL

\begin{tabular}{|c|c|c|c|c|c|c|c|c|c|}
\hline \multirow{4}{*}{ Drug } & & \multirow{4}{*}{$\begin{array}{l}\text { No.of } \\
\text { Cases }\end{array}$} & \multirow{4}{*}{$\begin{array}{c}\text { No } \\
\text { Response }\end{array}$} & \multicolumn{6}{|c|}{ Healed } \\
\hline & & & & \multicolumn{3}{|c|}{ Remained Healed } & \multicolumn{3}{|c|}{ Relapsed } \\
\hline & & & & \multirow{2}{*}{ Number } & \multicolumn{2}{|c|}{$\begin{array}{c}\text { Observation Period } \\
\text { (days) }\end{array}$} & \multirow{2}{*}{ Number } & \multicolumn{2}{|c|}{$\begin{array}{c}\text { Time Period } \\
\text { (days) }\end{array}$} \\
\hline & & & & & Minimum & Maximum & & Minimum & Maximum \\
\hline $\begin{array}{l}\text { Aureomycin } \\
\text { Chloramphenicol }\end{array}$ & .. & $\begin{array}{l}42 \\
16\end{array}$ & $\begin{array}{l}3 \\
0\end{array}$ & $\begin{array}{l}17 \\
12\end{array}$ & $\begin{array}{r}111 \\
16\end{array}$ & $\begin{array}{l}693 \\
207\end{array}$ & $\begin{array}{r}22 \\
4\end{array}$ & $\begin{array}{r}8 \\
33\end{array}$ & $\begin{array}{l}531 \\
101\end{array}$ \\
\hline
\end{tabular}

TABLE III

RESULTS IN SEVEN NEGRO FEMALES WITH GRANULOMA INGUINALE TREATED WITH INTRAMUSCULAR CHLORAMPHENICOL

\begin{tabular}{c|c|c|c|c|c}
\hline $\begin{array}{c}\text { J. H. H. } \\
\text { Ref. No. }\end{array}$ & $\begin{array}{c}\text { Duration of } \\
\text { Lesions } \\
\text { (months) }\end{array}$ & $\begin{array}{c}\text { Total Dose } \\
\text { (g.) }\end{array}$ & $\begin{array}{c}\text { Duration of } \\
\text { Treatment } \\
\text { (days) }\end{array}$ & Result & $\begin{array}{c}\text { Post-treatment } \\
\text { Observation } \\
\text { (days) }\end{array}$ \\
\hline 533438 & 12 & 18 & 9 & Healed & 236 \\
559352 & 24 & 10 & 10 & Healed & 167 \\
108821 & 15 & 15 & 15 & Healed & 140 \\
500429 & 24 & 10 & 10 & Healed & 121 \\
563872 & 18 & 10 & 10 & Relapse & 158 \\
383243 & 1 & 10 & 10 & Healed & 30 \\
141277 & 12 & 10 & Healed & 133 \\
\hline
\end{tabular}

phenicol, and terramycin ranking next in this order. Streptomycin and bacitracin are less active than any of these drugs.

Summary.-There are several objections to the treatment of gonorrhoea with aureomycin, terramycin, or chloramphenicol. Multiple oral dosage on an outpatient basis is unsatisfactory because of the uncertainty as to whether all medication will be consumed by the patient. I have shown that single-dose treatment, at least with aureomycin and terramycin, does not yield satisfactory cure rates. It is not economically feasible to use any of these drugs, whether by single or multiple dosage, as a routine clinic procedure. The suspension of chloramphenicol for intramuscular use is not commercially available, and therefore, penicillin remains the drug of choice in the treatment of gonorrhoea.

Granuloma Inguinale.-Terramycin may now be added to the list of drugs which heal the lesions of granuloma inguinale. The reports of various investigators indicate that it ranks in effectiveness with aureomycin and chloramphenicol. As with these other drugs, lack of adequate follow-up prohibited the formation of definite conclusions as to "cure rate". Greenblatt and others (1951) state there was complete healing of the lesions in 24 patients following terramycin therapy. Donovan bodies disappeared from lesions after 4 to 5 days of treatment. Hendricks and others (1950), Schock and Alexander (1950), Keefer (1950), and Whitaker and others (1951), concur in the opinion that it is a valuable drug. Reports on aureomycin and chloramphenicol administered orally, all favourable, continue to appear (Olansky and Landmann, 1950 ; Olansky and others, 1950 ; Poulin, 1950; Chen and others, 1951 ; Willcox, 1950e ; Greenblatt and others 1949, 1950a, b ; Zises and Smith, 1950, 1951 ; Wammock and others, 1950).

The results of long-term observation of patients treated with aureomycin and chloramphenicol have recently been evaluated (Robinson and Cronk, 1951); the number of relapses was considerably larger than in previously reported series, possibly because of more prolonged post-treatment observation. Only 50 per cent. of patients treated with aureomycin and 75 per cent. of those treated with chloramphenicol in various dosage schedules remained healed (Table II). We were unwilling to make a " cure rate" estimation, but the observation was made that chloramphenicol gave more rapid healing of early lesions.

The recent discovery (Moseley and Baroody, 1951) that chloramphenicol may be administered intramuscularly to humans without the severe local reaction which animal experimentation had led one 
to expect, has increased the usefulness of the drug in the treatment of granuloma inguinale. Harb, Simpson, and Wood (1951) treated 43 cases of granuloma inguinale with intramuscular chloramphenicol. Healing was prompt, but relapses were noted in five patients in from 21 days to 3 months. A preliminary evaluation of this mode of administration in granuloma inguinale has recently been completed (Robinson and Wells, 1952a, b). Each patient was given $1 \mathrm{~g}$. of the drug daily for 10 days. Healing began within a few days and was complete in some instances before the course of therapy was finished. Two relapses have been observed so far, at 2 and 5 months respectively after treatment was completed. On the basis of these failures the dosage has been increased to $2 \mathrm{~g}$. daily for 10 days (a total of $20 \mathrm{~g}$.). See Table III.

Summary.-We now have at our command four antibiotics effective in the treatment of granuloma inguinale : streptomycin, aureomycin, chloramphenicol, and terramycin. Out-patient treatment with streptomycin has been recommended by a few investigators, but many feel there are enough dangers attendant on administration of the drug for hospitalization to be necessary. Aureomycin and terramycin may be given intravenously or orally. Intravenous administration on an out-patient basis is not convenient in many institutions. Oral administration of any drug in the treatment of venereal disease is unsatisfactory. Oral administration of chloramphenicol has the same disadvantages, but early results obtained with the drug administered intramuscularly are encouraging enough for me to recommend this as a routine procedure for outpatients when the preparation is made available commercially.

Chancroid.-Willcox (1950b, c, d) has described three interesting experiments in which he evaluates the effectiveness of anti-chancroidal drugs by auto-inoculation of bubo fluid, and by heteroinoculation of bubo fluid of treated and untreated donors. His results indicate that sulphathiazole and streptomycin are effective both in preventing the experimental infection and in rendering the bubo fluid non-virulent within $24 \mathrm{hrs}$. Aureomycin and chloramphenicol were slightly less effective. Penicillin in sustained dosage was also competent, and seemed superior to single massive doses of procaine penicillin.

At the Philadelphia General Hospital terramycin was recently found to be capable of healing the lesions of chancroid (Niedelman and others, 1951). Other communications (Olansky and Landman, 1950 ; Willcox, 1950a, 1951; Greenblatt and others, 1950b; Nicol, 1951) substantiate our own observations (Robinson, 1950a ; Zheutlin and Robinson, 1950) that aureomycin and chloramphenicol also cause chancroidal ulcers to heal.

Summary.-There appears to be little reason for the treatment of chancroid with any of these newer drugs, for they cause no more rapid healing of the lesions than sulphathiazole or sulphadiazine, and are far more expensive. The treatment of choice is sulphonamide therapy, which has no effect on possible chancres, heals most chancroidal ulcers, causes resolution of most chancroidal buboes, and is cheaply available to out-patient clinics. Reactions to sulphonamides generally are not seen when the drug is given in short courses. If evidence of healing is not apparent within a week, one of the antibiotics should be tried.

Lymphogranuloma Venereum.-We have already seen that all the antibiotics derived from Streptomyces have indisputable effects on syphilis, gonorrhoea, granuloma inguinale, and chancroid. However, the early glowing reports of the effect of aureomycin on lymphogranuloma venereum gave rise to a conflicting series of laboratory and clinical investigations, the end of which is not yet in sight.

Olansky and Landman (1950) agree with us (Robinson, Zheutlin, and Trice, 1950) that, in general, aureomycin and chloramphenicol are disappointing. However, the influence of the favourable literature so outweighed our conservative views that the Ministry of Health in Great Britain (1949) issued the following communiqué :

Due to scarcity and high price, use of these drugs will be confined to treatment of specific conditions, including lymphogranuloma venereum.

Wright, Whitaker, and others (1951) and Wright and Prigot (1951) feel that the clinical response of lymphogranuloma venereum to terramycin is similar to that obtained with aureomycin. Wright, one of the original investigators in the field, insists that these drugs should be used in conjunction with surgery in cases of rectal stricture because of their specific action against the organism and general antibacterial activity. The original enthusiasm regarding the effect of the drug alone in rectal strictures has been tempered. Niedelman and others (1951) found terramycin to be more effective in the early than in the late manifestations of lymphogranuloma venereum, while the group in Georgia (Greenblatt and others, 1950b ; Wammock and others, 1950) claim that aureomycin is better in late lymphogranuloma venereum than in the bubo phase. Fletcher, Sigel, and Zintel (1951) found that inguinal adenitis and early proctitis 
showed an encouraging response while the chronic forms gave equivocal results. In contrast, Banov (1951) says that only one of twelve Negro women with rectal strictures failed to improve. Alergant (1950) had a good response in six patients with lymphogranuloma venereum, but Schamberg, Carrozzino, and Boger (1951) considered the response to aureomycin about equal to that obtained with sulphonamides over a longer dose period. Rowe (1951) feels that chloramphenicol should be a valuable adjunct in preparation for resection in advanced rectal stricture. It is generally agreed, however, that terramycin and aureomycin are more effective. Paulson (1951) feels that at least a considerable part of the response of proctitis to aureomycin rests in the control of the secondary infection with its consequent oedema around the anal sphincter. He recommends the prolonged use of sulphasuxidine by instillation and/or by mouth. The total daily dose used is $0.25 \mathrm{~g}$. $/ \mathrm{kg}$. bodyweight. No serious untoward reactions have been encountered.

Summary.-The contradictory results obtained by different groups of investigators leave one with a feeling of confusion. The bulk of the literature describing the reaction of the disease to the sulphonamides seems to favour the use of these drugs. Therefore, although I am of the opinion that buboes and proctitis respond more rapidly to aureomycin (and probably to terramycin), sulphathiazole and sulphadiazine are recommended as the drugs of choice for routine therapy.

Yaws.-Several reports (Loughlin and Joseph, 1951 ; Loughlin and others, 1951 ; Ampofo and Findlay, 1950a, b ; Payne and others, 1951) during the past 2 years indicate that chloramphenicol, aureomycin, and terramycin are effective in causing involution of the lesions of yaws. However, no evidence has as yet been presented which suggests any superiority over penicillin, which remains the drug of choice in treating this disease.

Investigations done in this clinic were supported by a grant-in-aid from the Research Grants and Fellowships Division, National Institutes of Health, United States Public Health Service.

Chloramphenicol was supplied by Parke-Davis and Company. Aureomycin was supplied by the Lederle Laboratories Division of the American Cyanamid Corporation. Terramycin was supplied by the Pfizer Company.

\section{REFERENCES}

Alergant, C. D. (1950). Lancet, 1, 950.

Ampofo, B., and Findlay, G. M. (1950a). Nature, Lond., 165, 398.

$-\frac{1}{315}(1950 \mathrm{~b})$. Trans. roy. Soc. trop. Med. Hyg.,
Banov, L. (1951). Amer. Surgeon, 17, 143.

Beinfield, M. S., Wright, L. T., DeLuca, F. R., Marmell, M., Metzger, W. I., Whitaker, J. C., and Wilkinson, R. S. (1951). N.Y. St. J. Med., 51, 1054.

Caldwell, E. R., Jr., Spies, H. W., Wolfe, C. K., Lepper, M. H., and Dowling, H. F. (1950). J. Lab. clin. Med.' 36, 747 .

Cantor, A. J. (1950). Amer. J. dig. Dis., 17, 340.

Chen, C. H., Dienst, R. B., and Greenblatt, R. B. (1950a). J. med. Ass. Ga., 39, 237.

,,$---(1950)$. J. Amer. med. Ass., 143, 724. ,,$---(1951)$. Amer. J. Syph., 35, 383.

Crane, G.' W., Jr., and McPherson, S. D., Jr. (1952). "The Effect of Local Cortisone in the Treatment of Syphilitic Interstitial Keratitis." Ibid., In the press.

DeLamater, E. D., Urbach, F., and Saurino, V. R. (1951). "Influence of Cortisone on Experimental Spirochetosis." Presented at the Fourth Annual Symposium on Recent Advances in the Study of Venereal Diseases, Washington, D.C.

Fitzgerald, J. R., Bellows, J. G., Donegan, J. M., Gamble, R. C., Krause, A. C., Mann, W. A., Pearlman, M. D., and Zekman, T. N. (1951). Arch. Ophthal., Chicago, 45, 320.

Fletcher, A., Sigel, M. M., and Zintel, H. A. (1951). Arch. Surg., 62, 239.

Geddes, A. K., and McCall, M. F. (1950). Canad. med. Ass. J., 63, 601.

Gocke, T. M., Wilcox, C., and Finland, M. (1950). Amer. J. Syph., 34, 265.

Greaves, A. B., MacDonald, G. R., Romansky, M. J., and Taggart, S. R. (1950). J. vener. Dis. Inform., 31, 261.

Greenblatt, R. B., Barfield, W. E., Dienst, R. B., and West, R. M. (1951). Ibid., 32, 113.

—, Wammock, V. S., Chen, C. H., Dienst, R. B., and West, R. M. (1950a). Ibid., 31, 45.

- , Dienst, R. B., and West, R. M. (1950b). Amer. J. Obstet. Gynec., 59, 1129.

,-- West, R. M., Dienst, R. B., and Chen, C. H. (1949). Amer, J. Syph., 33, 593.

Gruhzit, O. M., and Fisken, R. A. (1950). Ibid., 34, 338,

Harb, F. W., Simpson, W. G., and Wood, C. E. (1951). J. vener. Dis. Inform., 32, 177.

Hendricks, F. D., Greaves, A. B., Olansky, S., Taggart, S. R., Lewis, C. N., Landman, G. S., MacDonald, G. R., and Welch, H. (1950). J. Amer. med. Ass., 143, 4.

Keefer, C. S. (1950). Ann. N.Y. Acad. Sci., 53, 223.

Kierland, R. R., Herrell, W. E., and O'Leary, P. A. (1950). Arch. Derm. Syph., Chicago, 61, 185.

-, and O'Leary, P. A. (1950). Amer. J. Syph., 34, 443.

Klauder, J. V. (1951). Personal communication.

Leopold, J. H. (1951). Arch. Ophthal., Chicago, 45, 44. , Purnell, J. E., Cannon, E. J., Steinmetz, C. G., and MacDonald, P. R. (1951). Amer. J. Ophthal., 34,361 .

Loughlin, E. H., and Joseph, A. A. (1951). Antibiot. and Chemother., $1,76$.

Med., 31, 20.

Ministry of Health Announcements (1949). Med. Wld, Lond., 71, 460.

Mohr, C. F., and Robinson, R. C. V. (1952). “ "Aureomycin and Chloramphenicol in Treatment of Asymptomatic Neurosyphilis" (unpublished).

Moseley, V., and Baroody, W. G. (1951). J. S. C. med., Ass., 47, 157. 
Nicol, C. S. (1951). Practitioner, 166, 353.

Niedelman, M. L., Pierce, H. E., Jr., Hoffstein, L. D., and Matteucci, W. V. (1951). Amer. J. Syph., 35, 482.

Olansky, S., Hogan, R. B., Taggart, S. R., Landman, G. S., and Robin, E. D. (1950). Ibid., 34, 436.

, and Landman, G. S. (1950). Med. Ann. Distr. Columbia, 19, 491 .

Olson, J. A., Steffensen, E. H., Smith, R. W., Margulis, R. R., and Whitney, E. L. (1951). Arch. Ophthal., Chicago, 45, 274.

Paulson, M. (1951). Personal communication.

Payne, E. H., Bellerive, A., and Jean, L. (1951). Antibiot. and Chemother., 1, 88.

Poulin, J. E. (1950). J. Maine med. Ass., 41, 357.

Robinson, H. M., and Robinson, H. M., Jr. (1949). Sth. med. J., Bgham, Ala., 42, 988.

- - (1951). Arch. Derm. Syph., Chicago, 63, 687.

Robinson, R. C. V. (1950a). Amer. J. Syph., 34, 273. (1950b). Ibid., 34, 64, 587.

__ and Cronk, B. (1951). Ibid., 35, 378.

_- , and Galen, W. P. (1951). Ibid. 35, 488.

_ , and Oates, J. K. (1952). "Terramycin base in Treatment of Gonorrhea " (unpublished).

-_, and Wells, T. R. (1952a). "Intramuscular Chloramphenicol in the Treatment of Gonorrhea and Granuloma Inguinale." Ibid. In the press.

-

_- Zheutlin, H. E. C., and Trice, E. R. (1950). Ibid., 34, 67.

Romansky, M. J., Olansky, S., Taggart, S. R., Landman, G. S., and Robin, E. D. (1951). Ibid., 35, 234.

Rowe, R. J. (1951). Amer. J. Surg., 81, 42.

Sayer, R. J., Michel, J. C., Moll, F. C., and Kirby, W. M. M. (1951). Amer.'J. med. Sci., 221, 256.

Schamberg, I. L., Carrozzino, O. M., and Boger, W. P. (1951). Amer. J. Syph., 35, 370.

Scheie, H. G., Tyner, G. S., Buesseler, J. A., and Alfano, J. E. (1951). Arch. Ophthal., Chicago, 45, 301.

Schoch, A. G., and Alexander, L. J. (1950). Ann. N.Y. Acad. Sci., 53, 459.
Sheldon, W. H., Heyman, A., and Evans, L. D. (1951). "Failure of ACTH to Inhibit the Jarisch-Herxheimer Reaction in Rabbits Experimentally Infected with T. pallidum." Presented at Symposium on Recent Advances in the Study of Ven. Dis., Washington, D.C.

Simpson, W. G., Rosenblum, B. F., Wood, C. E., and Stammer, E. L. (1951). J. vener. Dis. Inform., 32, 116.

Turner, T. B., and Hollander, D. H. (1950). Bull. Johns Hopk. Hosp., 87, 505.

Wammock, V. S., Greenblatt, R. B., Dienst, R. B., Chen, C., and West, R. (1950). J. Invest. Derm., 14, 427.

Whitaker, J. C., Wright, L. T., Beinfield, M. S., Wilkinson, R. S.. and Marmell M., (1951). Antibiot. and Chemother. 1, 208.

Willcox, R. R. (1949). Brit. med. J., 2, 1076.

-(1950a). Ibid., 1, 467.

(1950b). Amer. J. Syph., 34, 378.

-(1950c). British Journal of Venereal Diseases, 26, 131.

—-(1950d). Arch. Derm. Syph., Chicago, 62, 533.

- (1950e). J. roy. Army med. Cps, 95, 167. -(1951). Brit. med. J., 1, 509.

_- and Findlay, G. M. (1949). Ibid., 2, 257.

Wilson, J. (1951). Memphis med. J., 26, 56.

Woods, A. C. (1952). "Treatment of Interstitial Keratitis with Cortisone and ACTH". Amer.J. Syph. In the press.

(1951). Editorial, Ibid., 35, 88.

Wright, L. T., Metzger, W. I., Beinfield, M. S., DiLorenzo, J. C., and Marmell, M. (1951). Urol. cutan. Rev., 55, 203.

-

, Whitaker, J. C., Wilkinson, R. S., and Beinfield, M. S. (1951). Antibiot. and Chemother., 1, 193.

Zheutlin, H. E. C., and Robinson, R. C. V. (1950). Amer. J. Syph., 34, 71.

Zises, M., and Smith, G. C. (1950). Arch. Derm. Syph., Chicago, 62, 642.

$\longrightarrow, \stackrel{C}{-}(1951)$. Amer. J. Syph., 35, 294. 